\title{
Three educational models for positioning the Maastricht research-based learning programme
}

Citation for published version (APA):

Bastiaens, E., van Merriënboer, J., \& van Tilburg, J. (2017). Three educational models for positioning the Maastricht research-based learning programme. In Research-based learning: Case studies from Maastricht University (pp. 35-41). Springer. https://doi.org/10.1007/978-3-319-50993-8_3

Document status and date:

Published: 01/01/2017

DOI:

10.1007/978-3-319-50993-8_3

Document Version:

Publisher's PDF, also known as Version of record

Document license:

Taverne

Please check the document version of this publication:

- A submitted manuscript is the version of the article upon submission and before peer-review. There can be important differences between the submitted version and the official published version of record.

People interested in the research are advised to contact the author for the final version of the publication, or visit the DOI to the publisher's website.

- The final author version and the galley proof are versions of the publication after peer review.

- The final published version features the final layout of the paper including the volume, issue and page numbers.

Link to publication

\footnotetext{
General rights rights.

- You may freely distribute the URL identifying the publication in the public portal. please follow below link for the End User Agreement:

www.umlib.nl/taverne-license

Take down policy

If you believe that this document breaches copyright please contact us at:

repository@maastrichtuniversity.nl

providing details and we will investigate your claim.
}

Copyright and moral rights for the publications made accessible in the public portal are retained by the authors and/or other copyright owners and it is a condition of accessing publications that users recognise and abide by the legal requirements associated with these

- Users may download and print one copy of any publication from the public portal for the purpose of private study or research.

- You may not further distribute the material or use it for any profit-making activity or commercial gain

If the publication is distributed under the terms of Article $25 \mathrm{fa}$ of the Dutch Copyright Act, indicated by the "Taverne" license above, 


\title{
Chapter 3 \\ Three Educational Models for Positioning the Maastricht Research Based Learning Pro- gramme
}

\author{
Ellen Bastiaens, Jeroen van Merriënboer \& Jonathan van Tilburg
}

E.T.W. Bastiaens, ellen.bastiaens@maastrichtuniversity.nl, + 3143 3884975; J.G. van Merriënboer, j.vanmerrienboer@maastrichtuniversity.nl, +31 43 3885727; J.H.O. van Tilburg, jonathan.vantilburg@maastrichtuniversity.nl, +31 433881623

\begin{abstract}
This chapter introduces three models describing approaches of research-based learning for the further refinement of undergraduate research at Maastricht University. The first model by Healey and Jenkins (2009) focuses on the role of the student (active participant or audience) and the scope of the research programme (research content or research processes and problems). The second model by Beckman and Hensel (2009) distinguishes eight continua for further refining the concept of undergraduate research. The third model by Van Merriënboer (1997) focuses on the level of maturity of the students and the level of independence provided to them during their research project. In the early days of the Maastricht Research Based Learning (MaRBLe) project there was little room to draw up a more structured approach for research-based learning. Introducing these models to the MaRBLe coordinators resulted in - to say the least - very interesting discussions among the coordinators, as the application of the models provided more in-depth insights into how research-based learning could be designed, and what it means to staff and students. Therefore, the models presented in this chapter will serve as analytical tools in order to capture the different forms of research-based learning as presented in this volume's case study chapters.
\end{abstract}

Key words: educational models, instructional design, research-based learning, undergraduate research

\section{Introduction}

In Chapter 2 we elaborated on the educational concepts of problem-based learning (PBL) and research-based learning (RBL) to create a framework for interpreting and analysing the case studies, which will be presented in the second section of 
this book. In this chapter we will introduce three more specific educational models which, in contrast to the broad educational concepts discussed in Chapter 2, provide concrete guidelines and principles for the design of RBL. This by no means implies that the case studies explicitly used these guidelines; most of them followed a bottom-up approach, and were strongly or almost completely based on the experience of the coordinators with developing education. Yet, the broad educational concepts presented in Chapter 2, the state-of-the-art and developments discussed in Chapter 1, and the more specific educational models presented in this chapter will be used to reflect on the case studies and to critically compare these MaRBLe experiences in Chapter 14.

\section{Model 1 Healey and Jenkins}

Bastiaens and Nijhuis (2012) tried to capture the different case studies of RBL at Maastricht University in the model of Healey and Jenkins (2009). In this model two axes are presented, leading to four quadrants for positioning RBL. The first axis represents the continuum regarding the role of the student: Is the student an active participant in the research or is the student placed in the role of audience? The role of the student also implies, almost automatically, the role of the staff: is the teacher student-focused or teacher-focused? The second axis distinguishes between the focus, which is either on research content or on research processes and problems. These two continua result in four types of curriculum models as presented in Figure 3.1:

1. The research-tutored curriculum accentuates students writing and discussing papers and essays.

2. In a research-led curriculum the content for the curriculum is selected primarily by the staff and the teaching method is traditional, meaning that information will be transferred to the students focusing on an understanding of research and its results.

3. The research-oriented curriculum emphasises teaching processes and skills of knowledge construction in a specific discipline or field of research.

4. In a research-based curriculum the curriculum defines the role of the student as actively conducting research himself and constructing new knowledge.

Since 2012 we further refined our understanding of the concept new in a researchbased curriculum, supporting a more distinctive positioning of the various programs at Maastricht University in the model. Elsen et al. (2009) provided us with a helpful categorisation. The authors use the criterion new only for student research that is original to the field or discipline. Furthermore, students are perceived as participants in research. On the other hand, if research only leads to new insights for the students themselves (thus, learning new knowledge) and not for the field or 
discipline, for instance, students were perceived as audience as opposed to participants.

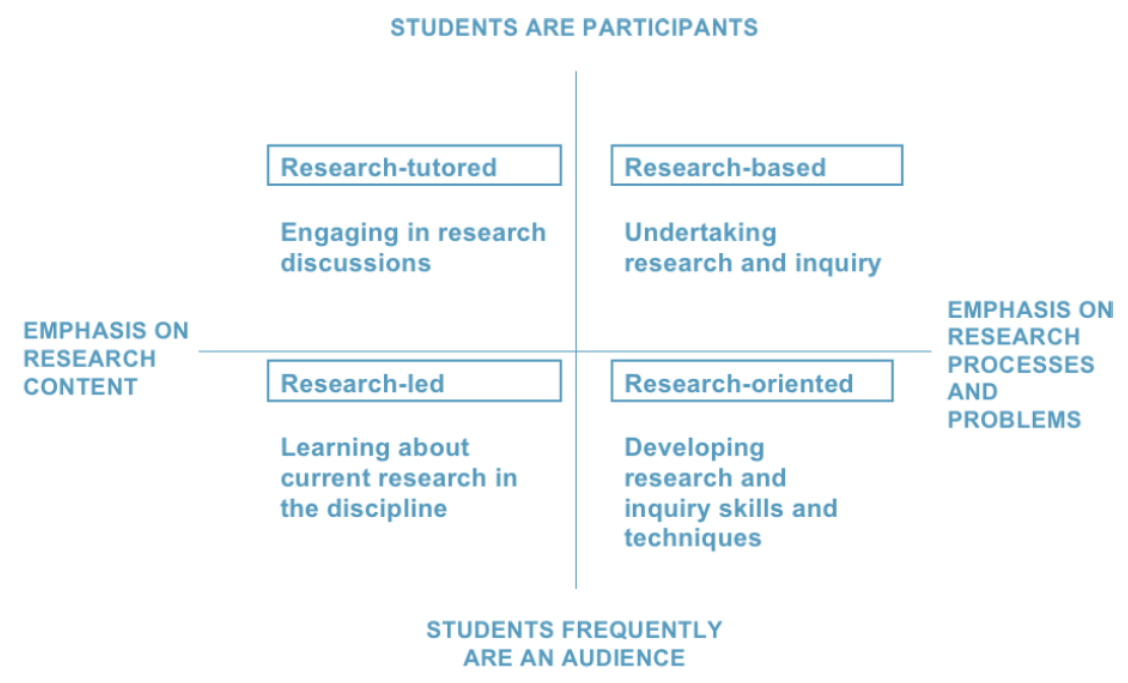

Fig. 3.1 Four types of curriculum models (Healey \& Jenkins, 2009, p. 7)

\section{Model 2 Beckman and Hensel}

A second helpful model is described by Beckham and Hensel (2009). As depicted in Figure 3.2, the authors distinguish eight continua for defining and refining models for RBL:

1. Student/process-centred or outcome/product-centred: the first case centralises the students' learning process, whereas the latter underlines the product or output.

2. Student-initiated or faculty-initiated: this continuum refers to the extent in which students have room to develop their own curiosity and interest in a specific research theme, or whether they are invited to join an existing staff research project.

3. Curriculum based or co-curricular fellowships: this continuum concentrates on deciding whether the research is embedded in the whole curriculum in a continuous trajectory throughout all years of a program, or whether a selection of the students will have the opportunity to participate in research as an addition to the regular curriculum by means of a fellowship.

4. Collaborative or individual: institutions must decide whether students collaborate or work individually on a research project. 
5. Original to the student or original to the discipline: the originality of a research project strongly relates to the before mentioned understanding of the concept new. New is generally defines as an original contribution to the research field or discipline. For students, however, new means acquiring new insights or perspectives which are applicable to addressing a specific research question.

6. Multi- or interdisciplinary research or discipline-based research: the discipline continuum refers to the relevance and the institute's value of the creation of opportunities for students to be engaged in multidisciplinary research, or the extent to which the research programmes focus on narrowly defined disciplines.

7. The campus/community audience versus professional audience continuum addresses the opportunities students have to present their research to the outside world. During the research project students are often supported in the development of their oral and written presentation skills. The extent to which this is limited to colleagues within the same faculty or to a broader (professional) audience can differ between programmes and disciplines.

8. All students versus honours students: this continuum defines the target group of the RBL programme. A programme's position within this continuum is influenced by the institution's decisions regarding the allocation of resources. Does the institution aim for all students to attain a certain level of research skills and experience, or does the institution support a selected group of students to develop a higher and more sophisticated level of research skills? In addition to the allocation of resources, the choice for the target group is also influenced by the students' abilities and interests.

The last continuum was not relevant for the cases studies presented in this book. By definition, the MaRBLe programme targets third-year undergraduate honours students, although some faculties slightly diverged from this guideline. 
Student, process-centered

Student-initiated

All Students

Curriculum-based

Collaborative

Original to the Student

Multi- or Interdisciplinary

Campus/community Audience
Outcome, product-centered

Faculty-initiated

Honours Students

Co-curricular Fellowships

Individual

Original to the Discipline

Discipline-based

Professional Audience

Fig. 3.2 Continua by Beckman \& Hensel (2009)

\section{Model 3 4C/ID Model by Van Merriënboer}

A third model focuses on the level of maturity and independence of the students in the process of conducting research. To address this aspect of RBL, we used the Four Components Instructional Design model (4C/ID). Van Merriënboer (1997) developed this model for designing educational programmes for the acquisition of complex skills; a use-oriented version of the model is elucidated by van Merriënboer and Kirschner (2012). We selected this model due to its focus on complex learning and provision of guidelines for sequencing and scaffolding. Zamorski (2002) states that the perceived relationship between students' intellectual maturing and the amount of support and guidance provided to them is a key concern for teaching staff, especially when decisions must be made on the nature and amount of research conducted by students. Scaffolding indicates that more support and guidance is provided at the beginning of a learning trajectory and that there is a gradual decrease of support provided to the students as they acquire more expertise, until the students can perform these complex skills independently (SpronkenSmith \& Walker, 2010). The 4C/ID model supports the development of educational programmes for complex learning. These programs are constructed from four interrelated components and the balance between these four components alters as the experience or maturity of the learners increases. The four components are:

1. Learning tasks: these are authentic whole-task experiences based on real-life tasks. The tasks aim at the integration of skills, knowledge, and attitudes. The 
learning tasks in a well-designed educational programme show variability of practice, are ordered from relatively simple tasks to increasingly more complex tasks, and show scaffolding on each level of complexity (i.e., decreasing support and guidance).

2. Supportive information: this type of information is helpful for learning and performing the non-routine aspects of learning tasks, such as problem solving, reasoning, and decision making. Supportive information explains how the field is organised and how problems can be systematically solved or approached.

3. Procedural information: this how-to information specifies how to perform routine aspects of learning tasks. Procedural information is best presented just in time, precisely when students need it.

4. Part-task practice: this type of practice supports students in reaching a high level of automaticity in executing routine aspects of learning tasks. Part-task practice generally provides a huge amount of repetition and is not offered until the routine aspects have been introduced to the students in the context of whole, meaningful tasks.

By sequencing the learning tasks from easy to complex and by gradually decreasing the amount of guidance, supportive information, and procedural information, students gradually develop complex cognitive skills and mature in their performance of the tasks. The 4C/ID model is, however, a general design model for complex skills. Table 3.1 translates the main concepts of the 4C/ID model to RBL.

Table 3.1 4C/ID Model by Van Merriënboer $(1997,2012)$

\begin{tabular}{|c|c|}
\hline 4C/ID Model & Translation to research-based learning \\
\hline Learning task & Executing a real-life research project \\
\hline Supportive information & $\begin{array}{l}\text { All information that is relevant to conducting research (for instance, } \\
\text { quantitative and qualitative research methods) }\end{array}$ \\
\hline Procedural information & $\begin{array}{l}\text { Job aids and manuals providing how-to instructions for performing } \\
\text { routine aspects of research tasks (e.g. creating setups in SPSS, and } \\
\text { constructing search queries for literature searches) }\end{array}$ \\
\hline Part-task practice & Data entry, use of formulas, applying APA guidelines, etc. \\
\hline
\end{tabular}

\section{Conclusion and Part II Preview}

In this chapter we presented three models that can provide specific guidelines for the development of RBL. Combined with the general educational concepts presented in Chapter 2 and the developments in the field discussed in Chapter 1, they provide a framework for reflecting on the case studies and critically comparing and contrasting them. This reflection will be provided in Chapter 14, accumulating in a description of the most important lessons learned. 
First, however, we will turn to the nine case studies. Chapter 4, The Psychology Student as Researcher, presents the implementation of the MaRBLe programme at the Faculty of Psychology and Neuroscience. The Faculty of Arts and Social Science's approach to the MaRBLe programme is elaborated in Chapter 5 The Adventure of doing Research. Chapter 6 On Expedition - Travels into the Unknown highlights the experiences and lessons learned from the student-centered research project on 16th and 17th century travel books. Changing Research Contexts: Collaboration with Non-academic Societal Partners in Research-based Bachelor's Projects (See Chap. 7) focuses on the benefits and challenges of involving nonacademic partners in undergraduate research projects. The nature of undergraduate research within Liberal Arts and Sciences programmes is elaborated in Chapter 8 University College Maastricht: The PEERS Project and Chapter 9 The Maastricht Science Programme: From Problem-Based Learning to Research-Based Learning in the Sciences. MaRBLe for Lawyers, Chapter 10, elaborates on the shift from faculty-initiated projects to student-initiated and student-driven research. Chapter 11 Data Science and Knowledge Engineering: From Knowledge Engineering to Knowledge Creation focuses on the amalgamation of the educational models project-centred learning and research-based learning. The case studies are concluded with a reflection on the implementation of MaRBLe at the School of Business and Economics in Chapter 12 Research-based Learning - an Implementation Journey.

\section{References}

Albanese, M. A., \& Mitchell, S. (1993). Problem-based learning: A review of literature on its outcomes and implementation issues. Academic medicine, 68(1), 52-81.

Barrows, H. S. (1996). Problem-based learning in medicine and beyond: A brief overview. New directions for teaching and learning, 1996(68), 3-12.

Bastiaens, E., \& Nijhuis, J. (2012). From Problem-Based Learning to Undergraduate Research: The Experience of Maastricht University in the Netherlands. CUR Quarterly, 32(4), 38-43.

Becher, T., \& Trowler, P. (2001). Academic tribes and territories: Intellectual enquiry and the culture of disciplines. New York: McGraw-Hill International.

Beckman, M., \& Hensel, N. (2009). Making explicit the implicit: Defining undergraduate research. CUR Quarterly, 29(4), 40-44.

Berkel, H. van (2010). Lessons from problem-based learning. Oxford: Oxford University Press.

Brew, A. (2003). Teaching and research: new relationships and their implications for inquirybased teaching and learning in higher education. Higher Education Research and Development, 22(1), 3-18.

Dewey, J. (1933). How we think: A restatement of the relation of reflective thinking to the educational process. Lexington, MA: Heath.

Edelson, D. C., Gordin, D. N., \& Pea, R. D. (1999). Addressing the challenges of inquiry-based learning through technology and curriculum design. Journal of the Learning Sciences, 8(3-4), 391-450.

Elsen, M. G., Visser-Wijnveen, G. J., Rijst, R. M. van der, \& Driel, J. H. van (2009). How to strengthen the connection between research and teaching in undergraduate university education. Higher Education Quarterly, 63(1), 64-85. 
Gijbels, D., Dochy, F., Bossche, P. van den, \& Segers, M. (2005). Effects of problem-based learning: A meta-analysis from the angle of assessment. Review of educational research, 75(1), 27-61.

Hattie, J., \& Marsh, H. W. (1996). The relationship between research and teaching: A metaanalysis. Review of educational research, 66(4), 507-542.

Healey, M. (2003). Promoting Lifelong Professional Development in Geography Education: International Perspectives on Developing the Scholarship of Teaching in Higher Education in the Twenty-First Century. The Professional Geographer, 55(1), 1-17.

Healey, M. (2005a). Linking research and teaching exploring disciplinary spaces and the role of inquiry-based learning. Reshaping the university: new relationships between research, scholarship and teaching, 67-78.

Healey, M. (2005b). Linking research and teaching to benefit student learning. Journal of Geography in Higher Education, 29(2), 183-201.

Healey, M., \& Jenkins, A. (2009). Developing undergraduate research and inquiry. York: Higher Education Academy.

Hensel, N. (2012). Characteristics of excellence in undergraduate research. Washington: Council on Undergraduate Research.

Hmelo-Silver, C. E. (2004). Problem-based learning: What and how do students learn? Educational Psychology Review, 16(3), 235-266.

Jenkins, A., \& Healey, M. (2005). Institutional strategies to link teaching and research. York: Higher Education Academy.

Kinkead, J. (2003). Learning through inquiry: An overview of undergraduate research. New directions for teaching and learning, 2003(93), 5-18.

Lee, O., Hart, J. E., Cuevas, P., \& Enders, C. (2004). Professional development in inquiry-based science for elementary teachers of diverse student groups. Journal of Research in Science Teaching, 41(10), 1021-1043.

Merriënboer, J. J. van (1997). Training complex cognitive skills: A four-component instructional design model for technical training. Englewood Cliffs, NJ: Educational Technology Publications.

Merriënboer, J. J. van, \& Kirschner, P. A. (2012). Ten steps to complex learning: A systematic approach to four-component instructional design. Abingdon: Routledge.

Neumann, R. (1992). Perceptions of the teaching-research nexus: A framework for analysis. Higher Education, 23(2), 159-171.

Savery, J. R. (2006). Overview of problem-based learning: Definitions and distinctions. Interdisciplinary Journal of Problem-based Learning, 1(1), 3.

Schmidt, H. G., \& Moust, J. H. (1999). Probleemgestuurd onderwijs: Praktijk en theorie. Groningen: Wolters-Noordhoff.

Spronken-Smith, R., \& Walker, R. (2010). Can inquiry-based learning strengthen the links between teaching and disciplinary research? Studies in Higher Education, 35(6), 723-740.

Vernon, D. T., \& Blake, R. L. (1993). Does problem-based learning work? A meta-analysis of evaluative research. Academic medicine, 68(7), 550-563.

Willison, J., \& O'Regan, K. (2007). Commonly known, commonly not known, totally unknown: a framework for students becoming researchers. Higher Education Research \& Development, 26(4), 393-409.

Wood, W. B. (2003). Inquiry-based undergraduate teaching in the life sciences at large research universities: a perspective on the Boyer Commission Report. Cell Biology Education, 2(2), 112-116.

Zamorski, B. (2002). Research-led teaching and learning in higher education: a case. Teaching in Higher Education, 7(4), 411-427. 